\title{
ZASŁUGI SEKCJI PATRYSTYCZNEJ PRZY KOMISJI EPISKOPATU W KOORDYNOWANIU STUDIÓW I PROPAGOWANIU MYŚLI OJCÓW KOŚCIOŁA W POLSCE
}

Zasługi Sekcji Patrystycznej przy Komisji Episkopatu ująłbym w pięciu płaszczyznach: pogłębianie wiedzy specjalistycznej wśród patrologów w oparciu o tematykę naukową zjazdów sekcyjnych, kwestia związana z dydaktyką patrologii, wymiana informacji i współpraca między patrologami w Polsce, troska o kwalifikacje kadry nauczającej, zaangażowanie w sprawy wydawnictw i publikacji.

1. Pogłębianie wiedzy specjalistycznej wśród patrologów. Sekcja Patrystyczna przy Komisji Episkopatu działająca w Polsce od 3 listopada 1977 r., organizuje corocznie zjazdy patrologów, które w swej zasadniczej części noszą charakter sympozjów naukowych. Zarząd Sekcji proponuje konkretny temat monograficzny, który powierza specjalistom danej dziedziny. Tematyka naukowa jest tak dobrana, by mogła stanowić pomoc dla wykładowców patrologii, a równocześnie dawała im możliwość zapoznania się z aktualnymi nurtami zainteresowań omawianej problematyki i literaturą na jej temat. Można powiedzieć, że na zjazdach sekcyjnych podejmowane są tematy wiodące, posiadające raczej wydźwięk praktyczny. Sekcja pragnie w ten sposób dostarczyć dydaktykom poszerzonej bazy źródłowej.

Wśród tematów, które były przedmiotem zjazdów sekcyjnych znalazły się m. in.: modlitwa starożytnych chrześcijan, teologia Soboru Efeskiego, Ojcowie Kościoła w kulturze polskiej, chrystologia Ojców, eklezjologia Ojców, Eucharystia w nauce Ojców, pneumatologia patrystyczna, mariologia Ojców, wczesnochrześcijańska asceza, ewangelizacja w epoce patrystycznej, godność chrześcijańska w nauczaniu Ojców ${ }^{1}$. Zapowiedzi tych spotkań, szczegółowy program oraz sprawozdania $\mathrm{z}$ ich przebiegu są regularnie od r. 1981 publikowane na

${ }^{1}$ Szczegółowy wykaz tytułów prelekcji wygłoszonych na tych zjazdach zob. ks. S. Longosz: 5-lecie Sekcji Patrystycznej, VoxP 2(1982) z. 2, 121-137; tenże, Sprawozdanie z działalności Sekcji Patrystycznej 1977-1983, VoxP 3(1983) z. 5, 486-487; tenże, XX lat działalności Sekcji Patrystycznej, VoxP 17(1997) z. 32-33, 585-595. 
łamach „Vox Patrum”. Prelegentami na zjazdach są w większości członkowie Sekcji, choć nie brakuje także specjalistów zapraszanych spoza Sekcji.

Na podkreślenie zasługuje fakt, że większość materiałów z dorocznych zjazdów Sekcji została wydana drukiem albo na łamach „Vox Patrum” lub w innych polskich periodykach naukowych ${ }^{2}$, albo w postaci oddzielnych publikacji zbiorowych ${ }^{3}$. Dzięki temu referaty o wartościowej treści, prezentowane wąskiemu gronu specjalistów docierają do szerszego grona czytelników, a rynek wydawniczy zostaje ubogacony nowymi pozycjami patrystycznymi. Patrologowie natomiast mają satysfakcję z pomnożenia dorobku naukowego.

2. Kwestie związane $\mathbf{z}$ dydaktyką patrologii. Sekcja Patrystyczna dużo uwagi poświęca kwestiom związanym $z$ dydaktyką patrologii, wśród których na pierwszy plan wysuwają się problem programu i metoda prowadzonych wykładów. W początkowym okresie działalności wykładowcami patrologii byli często specjaliści w innych dyscyplinach, zwłaszcza historii Kościoła. Wymagało to od zarządu Sekcji ukierunkowania metodologicznego i programowego wykładów. Na kolejnych zjazdach podejmowano więc konkretne zagadnienia praktyczne, takie jak: prowadzenie ćwiczeń z patrologii i ich egzemplifikacja, ramowy program wykładów i zakres tematyki nim objętej, metoda wykładu $\mathrm{z}$ patrologii i wynikające $\mathrm{z}$ niej miejsce patrologii w Ratio studiorum $^{4}$.

Należy zauważyć, że w czasie dyskusji na temat dydaktyki patrologii ujawniły się wśród członków Sekcji dwie tendencje, stanowiące wyraz dwóch szkół: historycznej i teologicznej. Z tendencji tych wynikały $\mathrm{z}$ jednej strony pewne różnice zdań w ujęciu programu wykładów, $z$ drugiej zaś przyczyniły się jednak do powolnego, ale systematycznego kształtowania syntezy, która uwzględniała doświadczenia dydaktyczne zarówno zwolenników metody teologicznej, jak i historycznej. Było to już dostrzegalne w sprawozdaniu ze stanu dydaktyki patrologii w Seminariach Duchownych w Polsce z 30 I 1987 r., które przedsta-

${ }^{2}$ Np. materiały z I spotkania Sekcji (1978) na temat: Modlitwa starożytnych chrześcijan pod red. S. Longosza, w: „Tarnowskie Studia Teologiczne” 8(1981) 1-248; z II spotkania (1979) na temat: Św. Bazyli w 1600 rocznicé śmierci, w: RTK 27(1980) z. 4, oraz w VoxP 2(1982) z. 3; z XX spotkania (1999) na temat: Millenaryzm u Ojców Kościoła, w: „Tarnowskie Studia Teologiczne” 19 (2000) 3-66.

Np. materiały z IV spotkania (1981) pt. Maryja w tajemnicy Chrystusa, red. S.C. Napórkowski - S. Longosz, Niepokalanów 1997; z XV spotkania (1993) pt. Ewangelizacja w epoce patrystycznej, red. F. Drączkowski - J. Pałucki, Lublin 1994; z XVI spotkania (1994) pt. Godność chrześcijanina w nauczaniu Ojców Kościoła, red. F. Drączkowski - J. Pałucki, Lublin 1996; z XVII spotkania (1995) pt. Droga doskonalenia chrześcijańskiego w epoce patrystycznej, red. F. Drączkowski - J. Pałucki, Lublin 1997; z XVIII spotkania (1996) pt. Ojcowie Kościota wobec filozofii i kultury klasycznej, red. F. Drączkowski - J. Pałucki, Lublin 1998; z XIX spotkania (1997) pt. Grzech pierworodny w nauce Ojców Kościoła, red. H. Pietras, ŹM 12, Kraków 1999.

${ }^{4}$ Zagadnieniu temu poświęcono również dedykowany J.M. Szymusiakowi XVI tom „Vox Patrum" zatytułowany: Nauczanie patrologii, Lublin 1990, 45-436. 
wił Komisji Episkopatu ds. Seminariów Duchownych ówczesny przewodniczący Sekcji - ks. B. Częsz. Znalazły się w nim następujące stwierdzenia: „Studium biblistyki uzyskało właściwe miejsce, właściwie zdecydowano o rozbudowie, kadrze i środkach, bibliotece i połączeniu programu $\mathrm{z}$ innymi dziedzinami oraz duszpasterstwem. Niestety, nie można tego powiedzieć o patrologii.

W związku z tym sugerujemy, aby w nowym Ratio studiorum:

a. wyraźnie nazwać patrologię dyscypliną ściśle teologiczną. Patrologia nie może być uważana za rodzaj wprowadzenia do teologii i w tym kontekście traktowana służebnie w stosunku do teologii dogmatycznej. Patrologia jest dyscypliną teologiczną, z której pomocy niewątpliwie korzysta teologia dogmatyczna, ale nie oznacza to, że klerycy muszą studiować patrologię przed rozpoczęciem studium dogmatyki. Wtedy bowiem jest to sprowadzenie patrologii do dyscypliny wyłącznie pomocniczej, a tym samym umniejszenie jej rangi. Patrologia nie może zastąpić historii teologii czy historii dogmatów. Uderzający jest brak w dotychczasowym programie właśnie historii dogmatów (wykłady $\mathrm{z}$ tej dziedziny mają tylko nieliczne Seminaria w Polsce). Patrologia tylko w stopniu bardzo ograniczonym może ten brak wypełnić.

b. wprowạdzić oficjalnie nazwę patrystyka w miejsce używanej dotychczas nazwy patrologia. W powszechnie przyjętym bowiem znaczeniu, w pojęciu „patrystyka” zawiera się pojęcie teologii Ojców Kościoła zarówno w sensie merytorycznym jak i rozwojowym, podczas gdy w pojęciu „patrologia” na pierwszym planie znajduje się aspekt historyczny, a więc dane biograficzne Ojców, ich spuścizna literacka i jej treść. Nazwa „patrystyka” ewidentniej ukazuje, że chodzi tu o dyscyplinę ściśle teologiczną.

c. określić miejsce patrystyki w wykazie przedmiotów bezpośrednio po biblistyce, a przed innymi dyscyplinami teologicznymi. Odpowiada to kolejności stosowanej w oficjalnych dokumentach kościelnych po Soborze Watykańskim II"

W ślad za określeniem miejsca patrystyki w Ratio studiorum, poszły sugestie odnośnie do ilości godzin wykładowych oraz ich rozmieszczenia w poszczególnych latach studiów. Sekcja stanęła na stanowisku, że dla zapewnienia patrystyce możliwości spełnienia jej zadań w całości studiów teologicznych, należy rozszerzyć wykłady na trzy semestry w wymiarze dwóch godzin tygodniowo. Warto w tym miejscu zauważyć, że postulat teñ znalazł potwierdzenie w wydanej później przez Kongregację ds. Wychowania Katolickiego Instrukcji o studium Ojców Kościoła z 10 XI 1989 roku6 ${ }^{6}$. Niestety, realizacja tego postu-

\footnotetext{
${ }^{5}$ Pełny tekst - zob. ks. B. Częsz, Zadania Sekcji Patrystycznej wobec dydaktyki dyscyplin patrystycznych, VoxP 9(1989) z. 16, 393-401.

${ }^{6}$ Jej tekst zob. m.in. VoxP 10(1990) z. 18, 7-39.
} 
latu, mimo jednoznacznych zaleceń Kongregacji, napotyka na trudności ${ }^{7}$, czego wyrazem była powtórna dyskusja na ten temat w czasie zjazdu Sekcji w Sandomierzu w 1993 roku. Z przykrością należy odnotować także fakt, że w tych ośrodkach, w których Instrukcję Kongregacji udało się wprowadzić w życie, jej dalsza realizacja jest zagrożona w związku z utworzeniem Kolegium Dziekanów Polskich Wydziałów Teologicznych, które na posiedzeniu w Poznaniu 18 III 1999 r. przyjęło tzw. program minimalny dla studiów magisterskich, dostosowany do programu ECTS stosowanego w krajach Unii Europejskiej, według którego dla patrologii przewidzianych jest tylko 60 godzin wykładowych jako obowiązkowych, a pozostałe 30 jako fakultatywnych do wyboru przez studenta.

Zasługą Sekcji są także zabiegi o to, by patrystyka jako dziedzina teologiczna była przesunięta na późniejsze lata studiów, najlepiej na rok III i IV. Wskazano, że da to okazję do lepszego ustawienia patrystyki w aspekcie duszpasterskim. Ojcowie są bowiem nauczycielami teologii nie rozczłonkowanej między różne specjalizacje, a więc teologii integralnej. Ma to znaczenie dla formacji alumnów, którzy w przyszłości mają głosić właśnie całościową naukę Bożą. W związku z tym zauważono, że przerabianie patrystyki na roku II mija się z celem, ponieważ studenci nie są jeszcze przygotowani do myślenia kategoriami teologicznymi, a ponadto są dopiero na początkowym etapie poznawania języków klasycznych: łaciny i greki.

Wydaje się, że ten postulat w większości ośrodków nauczania teologii w Polsce udało się wprowadzić w życie, tym więcej, że takie ujęcie zaleca też najnowsze Ratio studiorum.

3. Wymiana informacji i współpraca między teologami w Polsce. Stałym punktem zjazdów sekcyjnych jest wzajemne informowanie się uczestników o podjętych pracach naukowych, planach wydawniczych, a także zapotrzebowaniach naukowych na przyszłość. Uczestnicy mówią także o kierunkach badań, którym zamierzają się oddać. Staje się w ten sposób jasne nie tylko to, nad czym kto pracuje, ale także, które dziedziny patrystyki pozostają poza zasięgiem badań i wymagają jak najszybszego zainteresowania się nimi. Członkowie Sekcji są informowani, jakie pozycje książkowe, interesujące patrologa, ukażą się w najbliższym czasie. Regułą jest także wzajemne informowanie się o tematach aktualnie prowadzonych prac magisterskich i licencjackich $w$ poszczególnych uczelniach; tematy prac ukończonych publikowane są w „Vox Patrum”. Członkowie Sekcji biorą także aktywny udział w patrystycznych kongresach i sympozjach za granicą, z których składają krótkie sprawozdania w czasie zjazdów sekcyjnych.

${ }^{7}$ Por. Apel Sekcji Patrystycznej o zwiększenie godzin patrologii (20 III 1990), VoxP 10(1990) z. $18,451-552$. 
Nie udało się jednak dotąd Sekcji dokonać pewnej koordynacji badań naukowych między poszczególnymi ośrodkami. Jest to zadanie niewątpliwie bardzo trudne, chociaż - jak się wydaje - można już obecnie określić kierunek zainteresowań niektórych patrologów polskich, co znajduje swój wyraz w publikacjach o wyraźnym profilu specjalizacyjnym.

4. Troska o kwalifikacje kadry nauczającej. W początkowej fazie działalności Sekcji większość wykładowców patrologii - jak już to wyżej zostało wspomniane - stanowili specjaliści innych dziedzin, zwłaszcza historii Kościo$\mathrm{ra}^{8}$. Jeszcze w $1987 \mathrm{r}$. sytuacja taka miała miejsce aż w 14 Seminariach diecezjalnych w Polsce, nie licząc seminariów zakonnych. Kwalifikowani patrologowie byli w niewielkiej liczbie i reprezentowali głównie ośrodki akademickie w Warszawie, Krakowie, Lublinie, Poznaniu, Pelplinie i Tarnowie. Ten stan rzeczy ulegał powolnej, ale systematycznej poprawie. Warto przypomnieć, że kolejni przewodniczący Sekcji wielokrotnie osobiście zabiegali u biskupów diecezjalnych, aby zdecydowali się wysłać jakiegoś księdza na specjalistyczne studia patrystyczne. Zabiegi te na ogół były przyjmowane życzliwie i ze zrozumieniem, choć nierzadko dało się słyszeć głosy, że na pierwszym miejscu trzeba skompletować specjalistów z innych dziedzin. Stało się jednak faktem, że coraz większa liczba księży, rekrutująca się z różnych diecezji i z różnych zgromadzeń zakonnych, zdobywała wykształcenie specjalistyczne i to w większości przypadków w Rzymie na Instytucie Patrystycznym Augustinianum oraz w Papieskim Uniwersytecie Salezjańskim.

Dzisiaj, po ponad 20 latach działalności Sekcji, można z satysfakcją stwierdzić, że proporcje te ulegają zmianie. W zdecydowanej większości Seminariów Duchownych w Polsce patrystykę wykładają specjaliści tej dziedziny, z których bardzo wielu to absolwenci uczelni rzymskich. Za bezpowrotną przeszłość należy - miejmy nadzieję - uznać dramatyczne stwierdzenie ówczesnego przewodniczącego Sekcji ks. B. Częsza, wypowiedziane w czasie posiedzenia Komisji Episkopatu ds. Nauki Katolickiej w Warszawie 11 II 1987 r.: „Patrologia traktowana jest często po macoszemu, jako przedmiot do uzupełnienia etatu [...]. W niektórych Seminariach Duchownych wykładający patrologię zmieniają się co roku! W wielu seminariach zakonnych wykłady prowadzone są cyklicznie co 2 lata, a wykładowcy także się zmieniają"”.

${ }^{8}$ Por. referat ks. R. Andrzejewskiego: Sytuacja dydaktyczna patrologii w seminariach duchownych, wygłoszony 12 II 1974 w pałacu biskupim w Krakowie, na ogólnopolskim sympozjum zorganizowanym przez Międzywydziałowy Zakład Badań nad Antykiem Chrześcijańskim, oparty na ankiecie przeprowadzonej z polecenia ówczesnego przewodniczącego Komisji Episkopatu d/s Nauki Katolickiej ks. kard. K. Wojtyły, opublikowany później w RTK 26(1979) z. 4, 53-61.

${ }^{9}$ Por. ks. B. Częsz, Sprawozdanie z dziatalności Sekcji Patrystycznej 1983-1986, VoxP 7(1987) z. 12-13, s. 493, oraz tegoż autora: Zadania Sekcji Patrystycznej, art.cyt., VoxP 9(1998) z. 16, s. 395 396. 
5. Zaangażowanie w sprawy wydawnictw i publikacji. Niewątpliwym osiągnięciem Sekcji jest wydawanie materiałów naukowych zjazdów sekcyjnych drukiem, co zostało już wyżej wspomniane. Nie sposób też nie wspomnieć o aktywnej działalności pisarskiej i publicystycznej patrologów polskich. Rośnie liczba opracowań z dziedziny patrystyki, noszących niejednokrotnie charakter monografii. Niektóre z nich pojawiają się po raz pierwszy na gruncie języka polskiego. Dzisiaj młody adept wiedzy patrystycznej może znaleźć literaturę polskojęzyczną w zakresie najważniejszych tematów patrystycznych, podawaną w publikowanych w „Vox Patrum” bibliografiach. Ułatwia to oczywiście kierowanie pracami magisterskimi. Niewystarczająca jest ciągle liczba przekładów na język polski dzieł Ojców Kościoła, choć w ostatnim okresie znacznie wzrosła ich ilość. Niezastąpioną rolę w popularyzacji myśli Ojców Kościoła pełni periodyk „Vox Patrum”, w którym członkowie Sekcji mają możliwość zamieszczania swoich publikacji, jak również znalezienia interesujących materiałów, także z dziedziny dydaktyki.

Wydaje się, że ciągle aktualnym wyzwaniem dla wszystkich członków Sekcji Patrystycznej jest stan zaopatrzenia bibliotek Seminariów Duchownych w Polsce w księgozbiory patrystyczne. Kolejne zarządy Sekcji wielokrotnie zwracałý na to uwagę. Zależy to z pewnością nie tylko od wykładowców patrystyki, ale nie zwalnia ich z wysiłku i determinacji dla poprawienia istniejącego stanu rzeczy. W bibliotekach nie powinno zabraknąć ukazujących się przekładów i opracowań, a także czasopism z patrystyki i dziedzin jej pokrewnych. Wykorzystanie techniki komputerowej może także ułatwić dostęp do źródeł.

Byłoby dobrze, aby w ramach Sekcji Patrystycznej podjęto większy wysiłek w kierunku publikowania recenzji ukazujących się tłumaczeń i opracowań. Wiele cennych monografii, a także przekładów, mimo upływu czasu, nie doczekało się fachowych recenzji. Jest to jeden z największych braków i grzechów polskiej patrologii. Może byłoby dobrze na zjazdach sekcyjnych ustalić kto konkretnie napisze recenzję danej publikacji. Byłby to cenny przyczynek do popularyzacji myśli Ojców Kościoła w Polsce, w czym Sekcja Patrystyczna miałaby swój określony udział.

Podsumowując należy stwierdzić, że Sekcja Patrystyczna przy Komisji Episkopatu przez ponad 20 lat swojej działalności położyła wielkie zasługi spełniające na gruncie polskim misję ukazania Ojców Kościoła jako tych, którzy stanowią „trwałą strukturę Kościoła i w Kościele wszystkich czasów wypełniają niezmienną funkcję”, jak również - posługując się dalej sformułowaniami Jana Pawła II, zawartymi w Liście Apostolskim „Patres Ecclesiae” misję ukazania, że „wszelkie późniejsze przepowiadanie oraz nauczanie, jeśli chce być autentyczne, musi odwoływać się do [ich] przepowiadania i nauczania [...] i musi pasować do struktury niegdyś przez nich wzniesionej, z nią się 
zespolić i związać ${ }^{10}$. Za wypełnianie tej misji należy się Sekcji Patrystycznej przy Komisji Episkopatu uznanie i wdzięczność.

\title{
I MERITI DELLA SEZIONE PATRISTICA NEL PROPAGARE IL PENSIERO DEI PADRI IN POLONIA
}

\author{
(Sommario)
}

La Sezione Patristica presso la Commissione per l'Educazione della Conferenza Episcopale Polacca opera dal 1977. Essa ha un notevole influsso sia sulla didattica della patrologia delle accademiche scuole ecclesiastiche in Polonia che anche sulla divulgazione del pensiero dei Padri della Chiesa. Ogni anno si svolgono gli incontri di codesta Sezione che hanno come scopo non soltanto la presentazione delle diverse questioni concernenti la teologia dei Padri della chiesa, ma anche si occupano del programma di studio e degli esercizi al riguardo; oltre a ciò, durante questi incontri, ha luogo lo scambio delle informazioni sui lavori dei diversi centri di studi e sulle pubblicazioni. A cura di Sezione Patristica è aumentato il numero dei specialisti di patrologia in Polonia, i quali hanno fatto i loro studi specialistici prevelentemente a Roma.

${ }^{10}$ Epistola Apostolica „Patres Ecclesiae” 1, AAS 72(1980) s. 5, thum. OsRomPol 1980, nr 3, s. 14 lub VoxP 2(1982) z. 3, 247-248. 